\title{
Pre-European coastal settlement and use of the sea: A view from Queensland
}

\author{
Sean Ulm', Bryce Barker ${ }^{2}$, Andrew Border ${ }^{3}$, Jay Hall ${ }^{2}$, lan Lilley ${ }^{1}$, lan McNiven ${ }^{4}$, Robert Neal ${ }^{5}$ \\ and Mike Rowland ${ }^{\circ}$
}

We draw attention to important omissions in the chronology of Australian coastal occupation presented by Nicholson and Cane (1994) in their recent review of the subject. In the Queensland section of their review, Nicholson and Cane (1994:110-11) state that coastal settlement is confined to the last 2000 years in the Moreton Bay area, and to the last 1500 years for the remainder of the Queensland coast, with the exception of Princess Charlotte Bay, where occupation is dated to $4700 \mathrm{BP}$.

For the Moreton Bay area, Nicholson and Cane (1994: 111) make the erroneous claim that 'no sites older than 2000 BP have been recorded.' In fact, there are five reported coastal sites in this region (Hope Island, New Brisbane Airport, Sandstone Point, Toulkerrie and Wallen Wallen Creek) and two more immediately to the north (King's Bore Sandblow, Teewah Beach 26) which pre-date 2000 BP (Fig. 1, Table 1). These results have been published for some time and have been discussed extensively in the general literature (e.g. Lourandos 1993; McNiven 1992a, 1992b; Walters 1989, 1992a, 1992b).

Wallen Wallen Creek dates to at least 20,560 \pm 250 (SUA2341), but it is not considered to have been a coastal site until about $7500 \mathrm{BP}$ (Neal and Stock 1986). Four other coastal sites in the area are dated to earlier than $2000 \mathrm{BP}$, although results are not yet published.

Evidence from southeast Queensland comprises the largest regional coastal archaeological data set available in the state (and indeed one of the most extensively documented in Australia), with some 48 dated coastal sites. Although occupation in the region is evident around the time of sea level stabilisation, most sites are first occupied after $1500 \mathrm{BP}$. The implications of this chronology for models of cultural change in the region are discussed elsewhere (Hall and Hiscock 1988).

We also note that excavations on a number of offshore islands on the central Queensland coast are omitted from the Nicholson and Cane synthesis. Excavations at Mazie Bay on North Keppel Island (Rowland 1981, 1982a, 1983, 1985) and Nara Inlet 1 on Hook Island (Barker 1989, 1991) have revealed coastal occupation dating from the early to

1 Aboriginal and Torres Strait Islander Studies Uniţ, University of Qucensland, Brisbane, QLD 4072, Australia.

2 Department of Anthropology and Sociology, University of Queensland, Brisbene, QLD 4072, Australia.

3 Cultural Heritage Section, Department of Environment and Heritage, PO Box 5391, Townsville Mail Centre, Townsville, QLD 4810, Australia.

4 Department of Classics and Archaeology, University of Melboume, Parkville, VIC 3052, Australia.

5 Cultural Heritage Section, Department of Environment and Heritage, Jetset House, 288 Edward Street, Brisbane, QLD 4000, Australia.

6 Cultural Heritage Branch, Department of Environment and Heritage, PO Box 155, Brisbane, Albert Street, QLD 4002, Australia.

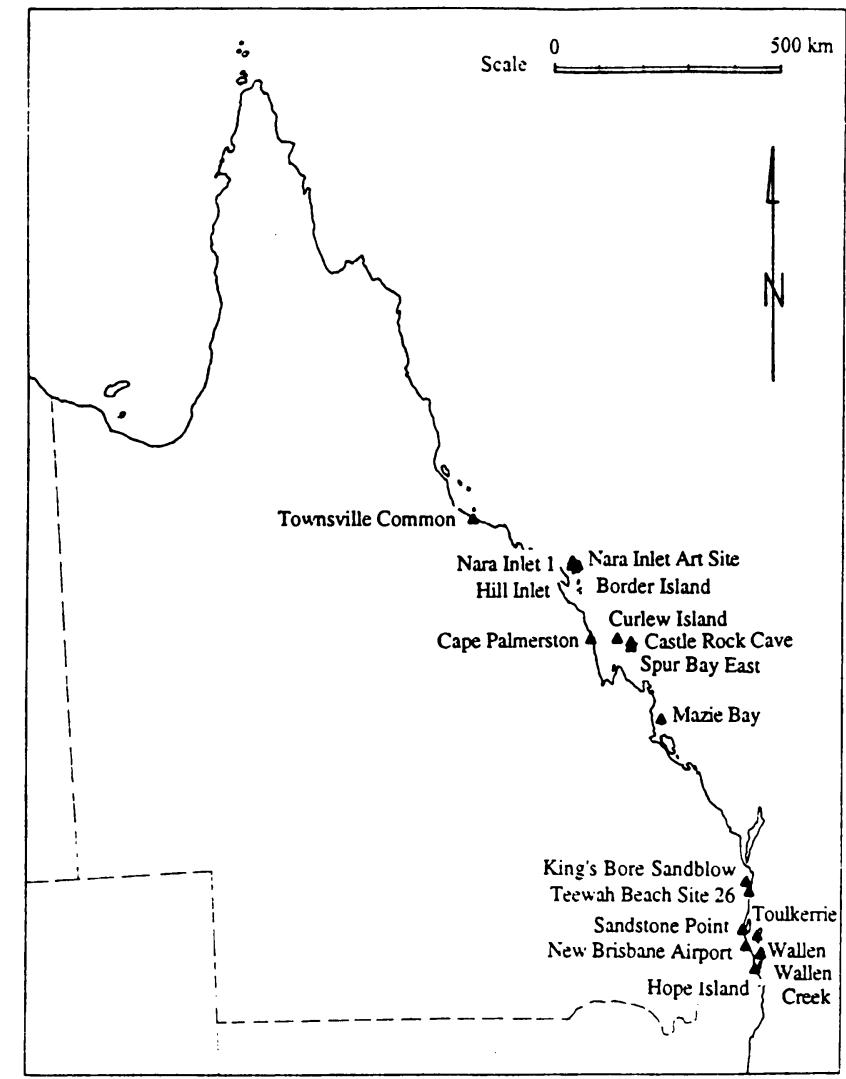

Figure 1 Queensland, showing sites referred to in the text.

mid-Holocene. Indeed, Barker's (1989, 1991, 1993) research in the Whitsunday Islands has provided the oldest evidence of human occupation within the Great Barrier Reef Marine Park with sites on Hook Island and Border Island dating to around $8000 \mathrm{BP}$ and $6500 \mathrm{BP}$ respectively. Barker's $(1989,1991)$ investigations at Hill Inlet on Whitsunday Island and Border's (1994) excavations on Curlew Island demonstrate occupation by about $3000 \mathrm{BP}$. Two other sites on Middle Percy Island (Castle Rock Cave and Spur Bay East), some $60 \mathrm{~km}$ from the present coast, were occupied prior to $2000 \mathrm{BP}$, indicating that marine-oriented cultural systems were well developed by this time (Border 1994). More recently, Barker and Schon (1994) have published a date for the Nara Inlet Art Site on Hook Island, also indicating occupation before 2000 BP.

Although few dated sites have been reported on the mainland coast between Fraser Island and Princess Charlotte Bay (cf. Campbell 1982a, 1982b; Rowland 1982b, 1989), sites at Townsville Common (Kelly 1982) and Cape Palmerston (Border 1994) have demonstrated coastal occupation dating before $2000 \mathrm{BP}$, in the first case by a substantial margin. 


\begin{tabular}{|llll|}
\hline Site & ${ }^{4} \mathrm{C}$ Age & Laboratory No. & Reference \\
Border Island & $6440 \pm 90$ & Beta-56976 & Barker 1993 \\
Cape Palmerston & $2350 \pm 70$ & Beta-64372 & Border 1994 \\
Castle Rock Cave & $2300 \pm 90$ & Beta-64373 & Border 1994 \\
Curlew Island & $2930 \pm 120$ & Beta-54204 & Border 1994 \\
Hill Inlet & $2720 \pm 120$ & Beta-34060 & Barker 1991 \\
Hope Island & $4350 \pm 220$ & Beta-20799 & Walters et al. 1987 \\
King's Bore Sandblow & $3560 \pm 100$ & Beta-25510 & McNiven 1992C \\
Mazie Bay & $4140 \pm 70$ & SUA-2183 & Rowland 1985 \\
Nara Inlet 1 & $8150 \pm 80$ & Beta-27835 & Barker 1991 \\
Nara Inlet Art Site & $2410 \pm 80$ & Beta-45186 & Barker and Schon 1994 \\
New Brisbane Airport & $3910 \pm 80$ & Beta-23345 & Hall and Lilley 1987 \\
Sandstone Point & $2290 \pm 100$ & Beta-15810/B & Walters 1989 \\
Spur Bay East & $2510 \pm 130$ & Beta-64374 & Border 1994 \\
Teewah Beach Site 26 & $4780 \pm 80$ & Beta-25512 & McNiven 1991 \\
Toulkerrie & $2290 \pm 80$ & Beta-32047 & Hall and Bowen 1989 \\
Townsville Common & $3760 \pm 130$ & GaK-7225 & Kelly 1982 \\
Wallen Wallen Creek & $6950 \pm 80$ & SUA-2343 & Neal and Stock 1986 \\
\hline
\end{tabular}

Table 1 Published pre-2000 BP dates for coastal sites in Queensland. All dates are on charcoal, except for Beta-56976 and SUA-2183 which are on marine shell.

We draw attention to this issue because we feel that Nicholson and Cane have omitted crucial data concerning Aboriginal use of the Queensland coast. We appreciate thdifficulty of providing an overview of what is now an extensive coastal literature. Nevertheless, Nicholson and Cane have failed to refer to some basic and easily available literature on the Queensland coast.

Occupation of the Queensland coast south of Cape York Peninsula is clearly not confined to the late Holocene as Nicholson and Cane suggest. We argue that both the Pleistocene and Holocene coasts of Queensland were extensively used by Aboriginal people and that further research is required to define the archaeological expression of these activities. Investigations at several sites (e.g. Nara Inlet 1 and Wallen Wallen Creek) have demonstrated the potential to locate long sequences on both the mainland and offshore islands (e.g. Barker 1991; Neal and Stock 1986), while the possibility of locating submerged sites on the continental shelf has been little explored. These views are consistent with the emerging pattern of coastal occupation for Australasia in general (e.g. Allen et al. 1989; Morse 1988, 1993; O'Connor 1989; Veth 1993; cf. Beaton 1985).

\section{References}

Allen, J., Gosden, C. and White, J.P. 1989 Human Pleistocene adaptations in the tropical island Pacific. Antiquity 63(240): 548-61.

Barker, B. 1989 Nara Inlet 1: A Holocene sequence from the Whitsunday Islands, central Queensland coast. Queensland Archaeological Research 6:53-76.

$\rightarrow$ Barker, B.C. 1991 Nara Inlet 1: Coastal resource use and the Holocene marine transgression in the Whitsunday Islands, central Queensland. Archaeology in Oceania 26(3):102-9.

Barker, B. 1993 Early human exploitation of island environments within the Great Barrier Reef Marine Park. Reef Research 3(3):13-14.

Barker, B. and Schon, R. 1994 A preliminary assessment of the spatial distribution of stone artefacts from the South Molle Island Aboriginal quarry, Whitsunday Islands, cen- tral Queensland coast. Memoirs of the Queensland Museum 37(1):5-12.

Beaton, J.M. 1985 Evidence for a coastal occupation time-lag at Princess Charlotte Bay (North Queensland) and implications for coastal colonisation and population growth theories for Aboriginal Australia. Archaeology in Oceania 20(1):1-20.

Border, A. 1994 Shoalwater Bay Military Training Area (SWBTA): A review of cultural heritage resources their significance and land use. In Commonwealth Commission of Inquiry Shoalwater Bay, Capricomia Coast, Queensland, Research Reports,.pp.173-233. No. 5, Vol. A. Canberra: Australian Government Publishing Service.

Campbell, J.B. 1982a Automatic seafood retrieval systems: The evidence from Hinchinbrook Island and its implications. In S. Bowdler (ed.) Coastal Archaeology in Eastern Australia: Proceedings of the 1980 Valla Conference on Australian Prehistory, pp.96-107. Canberra: Department of Prehistory, Research School of Pacific Studies, The Australian National University. Occasional Papers in Prehistory, No. 11.

Campbell, J.B. 1982b New radiocarbon results for North Queensland prehistory. Australian Archaeology 14:62-6.

Hall, J. and Bowen, G. 1989 An excavation of a midden complex at the Toulkerrie Oystermen's Lease, Moreton Island, S.E. Queensland. Queensland Archaeological Research 6:3-27.

Hall, J. and Hiscock, P. 1988 The Moreton Region Archaeological Project (MRAP) - Stage II: An outline of objectives and methods. Queensland Archaeological Research 5:4-24.

Hall, J. and Lilley, I. 1987 Excavation at the New Brisbane Airport site (LB:C69): Evidence for early mid-Holocene coastal occupation in Moreton Bay, SE Queensland. Queensland Archaeological Research 4:54-79.

Kelly, M. 1982 A Practical Reference Source to Radiocarbon Dates Obtained from Archaeological Sites in Queensland. Brisbane: Archaeology Branch, Department of Community Services. Cultural Resource Management Monograph Series, No. 4.

Lourandos, H. 1993 Hunter-gatherer cultural dynamics: Longand short-term trends in Australian prehistory. Journal of Archaeological Research 1(1):67-88. 
McNiven, I. 1991 Teewah Beach: New evidence for Holocene coastal occupation in coastal southeast Queensland. Australian Archaeology 33:14-27.

McNiven, I. 1992a Bevel-edged tools from coastal southeast Queensland. Antiquity 66(252):701-9.

$\rightarrow$ McNiven, I. 1992b Shell middens and mobility: The use of offsite faunal remains, Queensland, Australia. Journal of Field Archaeology 19(4):495-508.

McNiven, I. 1992c Sandblow sites in the Great Sandy Region, coastal southeast Queensland: Implications for models of late Holocene rainforest exploitation and settlement restructuring. Queensland Archaeological Research 9:1-16.

$\rightarrow$ Morse, K. 1988 Mandu Mandu Creek rockshelter: Pleistocene human coastal occupation of North West Cape, Western Australia. Archaeology in Oceania 23(3):81-8.

Morse, K. 1993 Who can see the sea? Prehistoric Aboriginal occupation of the Cape Range peninsula. In W.F. Humphreys (ed.) The Biogeography of Cape Range, Western Australia, pp.227-42. Records of the Western Australian Museum No. 45.

Neal, R. and Stock, E. 1986 Pleistocene occupation in the south-east Queensland coastal region. Nature 323:618-21.

Nicholson, A. and Cane, S. 1994 Pre-European coastal settlement and use of the sea. Australian Archaeology 39:108-17.

O'Connor, S. 1989 New radiocarbon dates from Koolan Island, west Kimberley, W.A. Australian Archaeology 29:30-9.

Rowland, M.J. 1981 Radiocarbon dates for a shell fishhook and disc from Mazie Bay, North Keppel Island. Australian Archaeology 15:63-9.
Rowland, M.J. 1982a Further radiocarbon dates from the Keppel Islands. Australian Archaeology 15:43-8.

Rowland, M.J. 1982b Stockyard Point - Capricorn coast: A brief note from terra incognita. Australian Archaeology 15: 35-42.

Rowland, M.J. 1983 A note on corrections to radiocarbon dates from the Keppel Islands. Australian Archaeology 17: 134-5.

Rowland, M.J. 1985 Further radiocarbon dates from Mazie Bay, North Keppel Island. Australian Archaeology 21:113-18.

Rowland, M.J. 1989 Population increase, intensification or a result of preservation? Explaining site distribution patterns on the coast of Queensland. Australian Aboriginal Studies 1989/2:32-42.

Veth, P. 1993 The Aboriginal occupation of the Montebello Islands, northwest Australia. Australian Aboriginal Studies 1993/2:39-57.

Walters, I. 1989 Intensified fishery production at Moreton Bay, southeast Queensland, in the late Holocene. Antiquity 63(239):215-24.

Walters, I. 1992a Farmers and their fires, fishers and their fish: Production and productivity in pre-European south-east Queensland. Dialectical Anthropology 17:167-82.

Walters, I. 1992b Antiquity of marine fishing in southeast Queensland. Queensland Archaeological Research 9. 35-7.

Walters, I., Lauer, P., Nolan, A., Dillon, G. and Aird, M. 1987 Hope Island: Salvage excavation of a Kombumerri site. Queensland Archaeological Research 4:80-95.

\section{Still flawed: A reply to Pardoe (1994) and Sim and Thorne (1994)}

\section{Peter Brown}

For different reasons I would like to thank the three authors (Pardoe 1994; Sim and Thorne 1994) who responded to my criticism of Sim and Thorne's (1990) research on King Island. Colin Pardoe agrees with my criticisms of Sim and Thorne's (1990) research methodology and the conclusions that they draw from it. However, he disagrees with my assertion that data of the type offered by Sim and Thorne should not be published. This is an important issue and I would like to discuss an example which I think may persuade him, as well as others with similar views, to change their minds. I must admit some surprise at the nature and content of the second reply to my article (Sim and Thorne 1994). While I think that they have scored a number of own goals some of their remarks do require discussion.

I have argued (Brown 1994) that data like those recorded by Sim and Thorne (1990) for the King Island skeleton should not be published as they cannot be corroborated or challenged by others. As a teaching academic I believe that the most important talent to develop in a student is a

Department of Archacology and Palaeoanthropology, University of New England, Amidale, NSW 2351 Australia. capacity for critical thinking. I would be appalled if one of my Honours students accepted an article I had published, or an article published by anyone else, at face value. It is essential to the future of our subject that students be encouraged to critically compare published data. This is only possible where observations have been recorded and discussed by a variety of people. Ideally this should be over an extended time period to account for changing research emphasis and methods of analysis. The alternative is a complete inability to distinguish fact from fiction and may as well be written as 'Mills and Boon' to begin with.

Pardoe (1994:7) argues that 'in a sense, there is nothing wrong with using data from skeletal remains that have been reburied' because the actual measurements may be corroborated by future discoveries. Although I agree that in an evolutionary sense it is the population that is important, rather than the individual, the history of our subject emphasises the importance of reassessment of individual fossils. I suspect that the books we read today may have had a very different emphasis if Piltdown had been lost in 1927 (Spencer 1990) and Taung had not been discovered (Dart 1925). After all we are members of a sexually dimorphic 